Received: 8/8/2019

UDK: 316.422-028.78:[37.016:37.014.3](497.5)

Preliminary communication

\title{
THE IMPACT OF THE 'CONSERVATIVE MODERNIZATION' ON THE EDUCATIONAL SYSTEM IN CROATIA: THE CONCEPTUAL AND IMPLEMENTATIONAL PRESSURES IN THE PROGESS OF COMPREHENSIVE GURRICULAR REFORM
}

\section{Ivan Beroš}

Faculty of Teacher Education

University of Zagreb

ivan.beros@gmail.com

Luka Pongračić

Faculty of Educational Sciences

Juraj Dobrila University of Pula 


\begin{abstract}
This paper points to different modes of agency that aimed and are still aiming at the transformation of social, political and economic discourse in the direction of 'conservative modernization' in most Western countries. The paper begins with a brief historical sketch of the socio-political circumstances that provided fertile ground for the emergence and development of 'conservative modernization', and continues to further elaborate the concept through the analysis of the categories that draw from works of the Michael W. Apple. The Apple's theoretical apparatus is applied as a 'tool' for the analysis of neoliberal, neoconservative, authoritarian-populist and expert conceptual and implementation pressures in the process of Comprehensive Curricular Reform in Croatia. The concluding section of the paper presents the results of the analysis of conceptual and implementation pressures in the process of Comprehensive Curricular Reform in Croatia.
\end{abstract}

Keywords: critical pedagogy, educational discourse, explicit and implicit aims of educational reform, politics of education, School for life 


\section{METHODOLOGICAL NOTE}

This paper starts with the description of the methodology of a theoretical research, results of which form the basis for the conclusions of this paper. The aim of this paper is to analyse the conceptual and implementational pressures of different socio-political actors in the process of theoretical design and practical implementation of the Comprehensive Curricular Reform in Croatia. The classification of actors in the educational policy used for this analysis, were constructed by Michael W. Apple. Apple (2012) divides socio-political actors who influence the theoretical design and practical implementation of educational policy into neoliberals, neoconservatives, authoritarian-populist religious conservatives and class of experts. As a method in realising the stated aim of this paper, the analysis of dominant socio-political discourses on the subject of Comprehensive curricular reform in the public sphere was used with the definition of political as a way of thinking, discussing and distributing values in the society (Gee, 2004) through the prism of dominant instance within each group of stakeholders. Different actors analysed in the paper have different starting point for understandings the reality which leads them to different interpretations of the same processes and different actions in practice (Jørgensen \& Phillips, 2002). Accordingly, the method of discourse analysis is used because it enables the exploration of the mode of use of (written and spoken) language 'in order to foster certain social activities and identities' (Gee, 2004, 1). Statements on the Comprehensive Curricular Reform served as units of analysis, which were placed in the public space by the dominant actors of each of mentioned group. Statements used for the purposes of this work were taken from the internet sites of conservative (Net. Hr and Dnevno.hr), liberal (Index.hr) and moderate (Srednja.hr) orientations. Analysed actors are classified as follows: Associations 'U ime obitelji', Vigilare and Hrast are designated as neoconservative, supranational instances of the World Bank and the European Union and their policies translated into labour market transformations in Croatia are classified as neoliberal actors. Also, HAZU representatives and the Ministry of Science and Education are classified as experts with associated value orientations: HAZU as neutral and the Ministry of Science and Education as a mixture of neoliberal and conservative orientation (resulting from its political orientation). 


\section{DEFINING 'CONSERVATIVE MODERNIZATION'}

What we noted and what motivated us for this article, is the presence of the 'conservative modernization' in the educational discourse ${ }^{1}$ at global, regional and local level. Michael W. Apple, the founder of the theory of 'conservative modernization' in the educational discourse, was the first to mention and elaborate the concept of 'conservative modernization' in 1979 in his book Ideology and Curriculum. Apple defines 'conservative modernization' as 'a movement that seeks to redefine the purpose and determine [the direction of] the further development of education, as a practice and expensive policy' (Apple, 2012, 380). The same definition applies today. This movement represents a community of the contradictory actors: neoliberals, neoconservatives, authoritarian-populist (religious) conservatives, and middle-class experts (Apple, 2012, 382-385). The answer to the question which group of actors is most powerful in the Comprehensive Curricular Reform process in Croatia is not straight-forward but one of the possible answers will be provided in this paper. Before answering this question, the development sketch of the role and importance of 'conservative modernization' actors in the Croatian context is presented together with the reasons why 'conservative modernization', in the opinion of the authors' of this paper, represents the dominant orientation in the economic, political and social systems in Croatia.

\subsection{Sketch of the role and Importance of Certain Actors of 'Conservative Modernization' in the Context of Croatia}

When trying to determine the hierarchy of influence of these actors in the context of Croatia, it becomes apparent that the class of experts have a role to service the needs and wishes of other classes. The class of experts is at the forefront when it becomes necessary to legitimize the need to initiate the process of the educational reform and theoretically conceptualize the reform. Yet, at the moment of its practical implementation into the educational practice, experts vanish from the discussion of reform efforts. When analysing the second group of actors - the neoliberals - the problem arises from the fact that these actors are twofold hidden; first, they are located outside of Croatia, and secondly they are scarcely present and known to the public sphere. ${ }^{2}$ This does not mean that they do not act, but

1 The discourse in this paper is understood in the broadest possible form, which means that it covers all interested actors, regardless of their legitimacy, ideological position and the scientific basis of the argument.

2 If they are present in the public sphere they are portrayed as positive actors who wish us all the best, which in practice is usually not true. However, the problem of instrumentalisation of the media in 
that their influence is more difficult to notice. Because they represent a neoliberal orientation, their influence should be visible in calls for the privatization of education, freedom of choice and greater teacher's responsibility, while reducing the expenditures for education. The privatization of education is currently not on the agenda after the successful blockade of the Faculty of Humanities and Social Sciences at the University of Zagreb by the students who have won the right to attend the higher education free of tuition. ${ }^{3}$ The stated does not mean that an appropriate set of circumstances, in which a complete privatization of educational system would be feasible in practice with a minimum of resistance, is not awaited. On the other hand, it can be seen that the state budget for education never has or hardly ever has sufficient funds.

Apple conducted analysis for construction of these categories in the US so the division to neoconservatives and authoritarian-populist (religious) conservatives proves to be justified. However, the authors of this paper believe that, in the Croatian context, the two groups are united under the auspices of the neoconservative (religious) current whose spokesmen are Željka Markić, the president of the Association U ime obitelji, Vigilare and its president Vice J. Batarelo, and HRAST and its president Ladislav Iličić. The difference between the neoconservatives and the authoritarian-religious populists is in the knowledge they seek to designate official through the national curricula (Apple, 1982; 2004; 2006; 2012). While there are differences between the two groups in the US where Apple conducted the analysis and the classification, the authors of this paper believe there are no such differences between the same groups in the Croatian context. Values and attitudes of the mentioned representatives of these two groups of actors in Croatia could be summarized as a celebration of heteronormative family and Christianity, the opposition to the rights of the LGBTQ community and the legalization of abortion. It could be said that they represent conservative values, their aim is to promote conservatism as a legitimate option" ${ }^{4}$ and the education is an important area of activity for them. ${ }^{5}$ However, in the case of Croatia, they do not have sufficient political power to impose religious dogmas throughout the curricula (with particular emphasis on history and biology), which places them at the neoconservative rather than extreme

Croatia and their overall lack of autonomy and criticism (especially in the case of HRT) is not the subject of this paper.

3 "The Land of Knowledge (Blockade of the Faculty of Philosophy in Zagreb 2009) Full Movie"(https:// www.youtube.com/watch?v=2VT LUmieLM) Site visited 12th November 2019.

4 (http://vigilare.org/tko-smo/) Site visited 12th November 2019.

5 For a more detailed analysis of this actor, see Apple (2006). We believe that the vast majority of what is written in this book can be translated into the current context of Croatia. 
authoritarian-populist end of actors in the process of educational policy making. The reason why we think it is justified to treat the two mentioned groups as one and which is neoconservative, is the absence of politically significant and potent demands for education based solely on Christian dogmas, which is a fundamental endeavour of religious-authoritarian populists as Apple (2006) defines them.

Although this paper researches the impact of 'conservative modernization' on the educational system and, consequently, the prevailing discourse (McLaren, 1995), it should be noted that this situation is an ideological 'spillover' from the socio-political system. Within the last four decades a growing power of conservative socio-political orientations could be seen in most Western countries around mainly social, economic and ideological controversies (Royce, 2010), and the same tendencies have been observed in young people from Croatia (Ilišin et al., 2013). With the collapse of the Soviet Union and the consequent disappearance of socialism from the socio-political scene, the conservative forces victoriously declared the end of history (Fukuyama, 1994) effectively preventing the creation of alternative socio-political narratives (Giroux, 2011; 2014; 2018a; 2018b).

\subsection{Analysis of Different Actors of the 'Conservative Modernization' in the Croatian Context}

In this part of the paper, we will endeavour to analyse each of these groups in greater detail, taking into account their main representatives (mainly associations and their official and unofficial spokespersons, i.e. holders of basic discourse) in the public sphere and their conceptual and implementational pressures in the process of the Comprehensive curricular reform. ${ }^{\mathbf{6}}$

\subsubsection{Representatives of the Neoliberals and their Conceptual and Implementational Pressures}

The representatives of neoliberals are numerous and they are united under the idea that the market is the element that determines the educational system to which the system is subordinate, so we conclude that they take over the dominant ideas of neoliberalism in education which are present in most developed western countries (Beroš, 2018b). The neoliberal representatives also believe that 'the influence of the school is not large' (Sesardić, January 7, 2018), so they do not understand why there are discussions on the purpose of education. Yet even though they do not understand it, they wholeheartedly hold STEM to be the content basis of the educa-

6 The Comprehensive Curricular Reform will be stated as CCR throughout the rest of the text. 
tional system (Sesardić, January 7, 2018). They advocate the commercialization of education, the idea with elitism and stratification of society on all issues as its core (Peović Vuković, May 31 ${ }^{\text {st }}$, 2017). The problematic nature of neoliberal conceptual pressures becomes apparent when the head of the expert working group (ERS) for CCR says that 'the very idea of curricular reform is 'entrepreneurial' (Jokić, 2016 according to Lukić \& Maslov, 2018, 306), and his successor states entrepreneurship as one of the fundamental values on which the reformed educational system should rest (Vican \& Glunčić, 2016 according to Lukić and Maslov, 2018, 306).

The question, then, is as follows: are not all the elements that make up parts of the CCR basically neoliberal? If we add to all of which has already been stated the fact that the drivers for reforming the educational system are poor results in PISA tests, the economic market (un)competitiveness of the state in international frameworks, and the need to educate workers capable of 21st century market struggles (Beroš, 2018b), we may wonder are neoliberal stakeholders the most important in the CCR process, and what are their implementational pressures?

The most obvious implementational pressure is certainly the aforementioned emphasis on the importance of entrepreneurship and its incorporation into the everyday life of the school. Furthermore, emphasizing the need for the education system to anticipate and advance the needs of the labour market places the ideas of employability, standardization and measurement at the centre of all theoretical and practical endeavours (Žiljak, 2009; Zhao, 2009; Sahlberg, 2015; Apple, 2006; Jarvis, 1993; Giroux, 2011; 2014). This becomes the explicit norm in adopting a curricular approach to planning and programming of the educational system that rests on the idea of competency. Now the new question arises: what are the implications of adopting a curricular approach to planning and programming of the educational system to the prevailing understanding of students from a psychological and pedagogical point of view?

Ćatić (2012) raises the question of the justification for the creation of curricula on competency approach and its focus on their development, as economic principles and the orientation to the efficiency of the entire educational system are introduced. With the adoption of competency approach, most of the power is obtained by the economic sector which transforms education into a commodity, while the really necessary competences remain in the background (Giroux, 2011; 2014). By unfolding the political changes in the society, at the same time the cognition develops. It also transcends the boundaries of geometric progression and creates unsurpassed knowledge, the control of which should be provided by a system of complementary competences. However, by adopting a competency-based approach to planning and programming the educational system, the exchanges 
based on pluralism do not happen and the consolidation of newly established relations (especially democratic ones) is neglected. That may be the reason for retaining the characteristics of totalitarian societies in school relations (Sekulić-Majurec, 2005). The competency-based approach to the educational process does not have a developed theory of the educational goals directed at the welfare of the society as a whole, nor a method for its eventual realization in practice.

The components and guiding lines of the school curricula according to Jurić $(2005,186)$ should be: ensuring the quality of teaching, parents and schools with a high degree of rapprochement, the concern for continuous learning and advancement, internal and external cohesion, the rational use of working time, the care for ideal learning conditions and encouraging open communication. These components represent the pieces needed for the proper steering of the democratic and contemporary curricula. An important part of the contemporary school curricula is its hidden part, which 'brings together all the publicly unrecognized, disowned and unforeseen values, knowledge and attitudes that students emphasize and transform into behavioural life patterns. The implicit messages are embedded into the structure of the public curricula across goals, values, content and expected outcomes' (Mlinarević, 2016, 14). The responsibility of teachers to fulfil its own commitment to the competencies and professionalism requirements that this approach requires of them also plays a prominent role (Hrvatić \& Piršl, 2007). Acquiring different and usable competencies is the (theoretical) aspiration of the educational system. From a competency-based perspective, the most important competence is knowledge that is usable (Keane, 2016) and offers a transition to a higher level than factual, and ideas need to be new and original (Baer, 2012). In a transition to the standardized curricula, technocratic governance and (political) control of educational manifests and the absence of a pedagogically and scientifically based approach to the educational reform becomes visible (Marsh, 1994; Palekčić, 2007). Furthermore, the position of the educational system as one of the social subsystems (Pastuović, 1999) highlights the hidden side of the systematic alteration of problematic areas of social subsystems, which can become an overly complicated undertaking. This thinking leads us to the need for major changes of the basic social values. The curricula design should strive to the knowledge and values that are important for preparing the students for after-school life (Howe, 2002).

The core values underlying the neoliberal orientation, perceived as a dominant sociological paradigm, are 'uncertainty and risk' (Lukić \& Maslov, 2018, 309). By accepting these core values as those that determine the process of the CCR, originating from the immediate socio-economic reality (Vrančić et al., 2016 according to Lukić \& Maslov, 2018) into which the educational process is immersed, it fol- 
lows that the need to educate individuals capable to adapt to constant risks and change is a supreme imperative. In order to achieve this, the state must have a direct control over the educational system (Karsten, 1999) to be sure that the system as a result provides individuals with a certain set of competencies. For the state to be sure that individuals after completing a certain level of education possess the set of competencies envisaged by the curricula, the quality control is performed through national tests, i.e. the state matriculation in the case of Croatia. After the quality control has been carried out, a ranking of the performance of schools and individuals at the state matriculation examination is created (Božić, 2018), which satisfies the neoliberal requirement for accountability of school toward students/consumers (Gordon \& Whitty, 1997). The aforementioned imperative to educate individuals ready to enter the (existing) labour market and accept the continuous competition is not questioned in the process of the CCR, and the prevailing opinion is that it does not need to be legitimized at all, since it represents the only option for reform activities from the perspective of neoliberals. There is also no discussion of the difficulties associated with measuring the outcomes of the educational process and comparing different schools for the purposes of ranking (Ball, 2007).

\subsubsection{Representatives of the Neoconservative (Authoritorian- Populist) Current and their Conceptual and Implementational Pressures}

As explained earlier in this paper, the authors have approached the analysis of authoritarian-populist and religious-conservative actors in the educational system as a group united under the neoconservative current. As a dominant actor in this field, the association U ime obitelji and its unofficial spokeswoman Željka Markić stand out. The said Association 'was created on the activities of the civic initiative 'On behalf of the family', which brings together individuals, families, civic and religious associations, communities and movements - all those who promote universal human values - marriage and family. ${ }^{7}$ As stated in the Association's Statute (Article 6), the goals and activities of the Association focus on family and family values, marriage, motherhood and paternity, ${ }^{8}$ as well as the cultural activities that contribute to the realization of these values, and the areas of activity of the Association, in accordance with its objectives, are inter alia education, science and

7 (https://uimeobitelii.net/preuzmi/) Site visited $12^{\text {th }}$ November 2019.

8 Statute of the Association U ime obitelji (https://uimeobitelij.net/wp-content/uploads/2018/09/Statut17Jul18.-iz-Registra-udruga.pdf) Site visited 12th November 2019. 
research. ${ }^{9}$ Furthermore, in the first successful referendum in the Republic of Croatia, which resulted in the 'constitutional definition of marriage as a union of men and women' (Petričušić et al., 2017, 61), The Association U ime obitelji insisted that the 'traditional values of Croatian society should be protected by the sanctification of (italics I.B.) traditional, heteronormative definitions of a family' (Petričušić et al., 2017, 61). The fact that the results confirmed the referendum question made it clear that the 'Croatian society is conservative' (Petričušić et al., 2017, 62).

This paper raises the question about the quality and quantity of conceptual and implementational pressures that the Association directed towards CCR since it explicitly cites education as one of its areas of activity.

The authors of this paper believe that the Association U ime obitelji occupies the role of an opponent (Kovač, 2007) in the process of CCR processes, and the reasons for this conclusion are given below. One of the ways of obstruction of the reform efforts used by the said Association is the flooding of the media space ${ }^{10}$ in which the CCR-related dialogue was to develop. This form of obstruction is complemented by turning scientific debate and reform efforts into the ideological quarrels and placing non-existent reform motivators (Sahlberg, 2015) at the centre of public media discourse. Without any argument, Željka Markić writes that 'politically motivated and indoctrinated educational reform is equally dangerous and bad for our children and the future of Croatia when implemented by Milanović's head of the ERS Jokić and when implemented by Plenković's head of the ERS Divjak' (Veronika S, September $14^{\text {th }}$ 2017). According to this statement, in the opinion of Željka Markić, the motive for the reform efforts is an ideology, not a desire to bring the Croatian education system closer to the best educational systems in the world. The Association's implementational pressures became most evident in the Croatian language curricula, which the Association opposed 'seeking to remove authors such as Zoran Ferić, Kristian Novak, Dubravka Ugrešić and Slavenka Drakulić from the reading list. The Association claimed that these authors were directing young people to the topics of sexuality and that in this way pupils were going to become addicted to pornography, rather than develop the need to read the classics and expand the intellectual horizons, which is contrary to the moral dimension of the school and teaching of the Croatian language' (Pauček Šljivak, Februrary $6^{\text {th }}$ 2018).

Criticizing the proposed choice of books to be included in the mandatory reading list (and proposing its own list), Željka Markić takes on the role of an indi-

9 Cf. Ibidem.

10 A search on Google with the keywords 'Željka Markić' and 'education reform' produced 19,600 results on October $11^{\text {th }}, 2019$. 
vidual who has the right to determine the content of the curricula, thus obstructing the efforts based on the dialogue of all interested stakeholders. And finally, the power of (mostly conceptual) influences of the Association $U$ ime obitelii in the process of the CCR became evident by the election of Jasminka Buljan Culej as the 'head of the expert working group for the implementation of curricular reform' (Kukec, 2017). This is significant because Buljan Culej is 'a person close to Željko Markić's circles' (Kukec, 2017).

One more conservative actor who has taken an ambivalent position towards the the CCR is the National Council for Education in which six of the eight members came from conservative circles (Brkulj, June $\left.1^{\text {st }}, 2017\right)$. The very fact that 'there are no specific criteria, nor is it stated anywhere who elects [members of the Council] within the Ministry and by which criterion, other than those stated in the public invitation' (Brkulj, June $1^{\text {st }}, 2017$ ), casts doubt on its legitimacy. The National Council for Education is 'a strategic body that monitors the quality of the pre-school, primary and secondary education system in Croatia' (Brkulj, June $\left.1^{\text {st }}, 2017\right)$. Therefore, if their members are of the conservative orientation, it then prevails a shift made from the initial ideas on which the CCR was based. Since the Council has an evaluative role, it is easy to imagine that the value preferences of members will play a role in the exercise of the Council's role. Thus, for example, Council member Valentina Jerković 'during 2013 and the Referendum on the constitutional definition of marriage, was (...) the the coordinator of the association $U$ ime obitelji for the Primorsko-Gorska county' (Krštul, May $28^{\text {th }}, 2017$ ).

\subsubsection{Representatives of the Class of Experts and Their Conceptual and Implementational Pressures}

The most prominent representatives of the class of experts are the members of the Croatian Academy of Sciences and Arts (HAZU), and their 'spokesperson' Vladimir Paar, the President of the Scientific Council for Education of HAZU. Their pressures, which we will analyse in this section, are mostly conceptual and less implementational in nature. The members of HAZU consider that at the conceptual level, the 'CCR is full of errors, wrong conceptions, vague formulations and profound misunderstandings of the teaching content and methods' (Paar \& Šestić, 2017, 24), and 'certain segments of the CCR made by members of The Expert Working Group and subject committees are not in line with the scientific facts and findings, probably as a result of a lack of deeper knowledge of the parent scientific disciplines, so they need to be rewritten' (Paar \& Šestić, 2017, 25). It is interesting that HAZU also refers to teachers who should implement the CCR and states that 
'teachers in Croatian schools are not sufficiently qualified at the moment and the needed material and technical preconditions for major and abrupt changes in the existing education system are not in place’ (Paar \& Šestić, 2017, 25). They also claim that 'the CCR is not aligned with the programs of institutions that educate primary and secondary school teachers who should implement it' (Paar \& Šestić, 2017, 25).

The implementational pressures of HAZU are expressed through the Recommendations of the Scientific Council for Education of HAZU. The Council believes that it is necessary to expand the expert working group before reforming the educational system and carry out a thorough analysis of the current situation, with the constant supervision of the highest state body, that is, the Parliament of the Republic of Croatia' (Paar \& Šetić, 2017, 26). They also believe it is necessary to change the methodology of the CCR. HAZU believes that 'the central issue for successful realisation of the curricular reform is the prior intensive and continuous professional training of teachers and professors with adequate material and status incentives and proper school equipment' (Paar \& Šetić, 2017, 26).

\subsubsection{A Review of the Implementational and Conceptual Pressures of Different Representatives}

In a discussion surrounding the CCR, neoliberal representatives were the most vocal group in the implementational and conceptual terms, pointing toward (how they believe) the only possible aim of the educational system, i. e. the everincreasing degree of the employability and the international competitiveness of the Croatian economy. Although their position indicates the instrumentalists' understanding of the goals of the educational system with an exclusive (implicit) emphasis on maintaining the socio- political status quo, they believe that the debate on the CCR should be removed from the grip of ideology and directed toward the future. The experimental implementation of the CCR through the 'School for Life'11 project indicates that neoliberal representatives have succeeded in putting this idea into practice. In the case of the 'School for Life' only the form remained relevant, which is illustrated by the fact that tablets arrived in only 11 of the 74 'Schools of life' and are being continously used in only four (Gelenčir, 2018). In the preparation of 'School for Life', tablets became synonymous with CCR, teacher training through Loomen ${ }^{12}$ proved to be insufficient and inadequate for the front-end

11 'School for life' has almost no common elements with CCR's conceptual and practical ideas, but we will not discuss this in more detail in this paper.

12 „CARNET Loomen is a complete online distance learning platform. CARNET Loomen enables users 
implementation of the 'School for Life' curricula, the curricula differ from those tested in experimental schools, the results achieved by students involved in experimental implementation of the 'School for Life' are lower than expected and there is no political consensus on the future of the CCR (Krštul, 2019a). Neither should the financial background of the 'Schools for Life' project, which has not been bypassed or the corruption scandals, be overlooked. Specifically, 'tens or more hundreds of thousands of kunas were paid to individuals, mainly teachers who worked on the preparation of the pilot school, in the nine months of 2018 from the EU project 'Support for the implementation of the Comprehensive Curricular Reform' (CCR I)' (Krštul, 2019b, highlighted in the original). As it was written, the 'School for Life' is basically a neoliberal project with the final result in the transfer of public funds to private accounts, i.e. it shows the dominant influence of the neoliberal actors on the implementation of CCR in practice.

The experimental implementation of the 'School for Life' neglected all the problems that (if the Ministry of Education wanted the project to be successful) had to be solved. The infrastructure of some schools that participated in the experimental implementation of the 'School for Life' does not meet the legal standards, the teaching materials were not prepared on time, the teachers were not sufficiently qualified to introduce the announced changes or did not have the necessary support. Ultimately, the overall climate created around the 'School for Life' was not stimulating but threatening for most teachers.

Representatives of the neoconservative current were the most vocal in conceptual terms. While looking at the curricula that form the backbone of the 'School of Life', it becomes evident that the representatives of this group had a strong value and conceptual influence on the development of teaching materials. Furthermore, in the fact that Civic education is still conceived and implemented in practice as a cross-curricular theme ${ }^{13}$, tendencies of conservative orientation in the educational system are obvious while the system is cleansed of controversial, critical, economic and political issues that may lead to questioning and conflicting with the prevailing social-political and economic dogmas. Finally, after the initial phase, representatives of the class of experts have almost completely disappeared from the discourse of the CCR and have been reduced (by their own decision) to the role of

to take and author courses, test knowledge, hand in and control assignments, make attendance records and use communication platform. In addition, it offers a number of other options that can, in some cases, completely replace the classic classroom, but also provide opportunities that we cannot achieve with conventional teaching methods" (https://www.carnet.hr/usluga/loomen/) Site visited 23rd November 2019.

13 Although research shows that the educational outcomes of this area are more successfully realized when civic education is conceived as a stand-alone subject (see Sinclair, 2004; Oxfam, 2006) 
observers, who became involved when it was necessary to legitimize the dominant educational discourse. The fact that the class of experts readily conceded its leading role in the process of the CCR to marginal associations and political groups is worrying, as it indicates the alienation of intellectuals from everyday life and their sterile inability to put into practice their own theoretical ideas. In this way, the experts hand on the implementational phase of the CCR to those who are seeking a way to achieve their particular goals in education. Experts halted their reform efforts at a crucial moment and from that fact it could be concluded that the class of experts did not involve in the reform process willingly but were pushed into it by their role as experts in specific areas of science.

\subsection{Educational Reality through the Prism of the 'Conservative Modernization"14}

Now we stand before the question of what is the situation in the Croatian educational system. HZZ ${ }^{15}$ makes recommendations for employment in every county every year, and the situation is generally known: we need services and manufacturing workers that (largely) do not require higher education but secondary education, and as far as the higher education is concerned, we lack students who graduate in the medical, mathematical, physical, mechanical engineering and electrical engineering areas (HZZ, 2016). ${ }^{\mathbf{1 6}}$ The neoliberal turn is also present in Croatia (but not so pronounced), which is evident from the questions posed by Jutarnji List journalist Mirela Lilek 'A big analysis of cause: where did we all go wrong? Why are we bad at PISA tests and why doesn't anyone get upset?' (2016).

From the introductory paragraph, two conclusions emerge: the education in Croatia does not meet the needs of the labour market (and neoliberals say this is the basic function of the educational system) and no one is upset (and should they be?) because of the poor results of PISA tests. Let us start from the bottom: Finns were in awe and did not know what was happening when they came first in the 2000 PISA examination (Sahlberg, 2015). What we want to emphasize is the reverse logic in the cases of Croatia and Finland. Finns have created quality education for the children and young people who it was initially intended for. Their main

14 This part of the paper was taken from an earlier published paper (Beroš, 2018b) because we believe that nothing has changed significantly since the publication of this paper the aforementioned analysis still corresponds to the real situation in the field of educational policy. However, minimal changes have been made to fit the situation as accurately as possible.

15 Croatian employment service.

16 A large proportion of graduates go to European and Scandinavian countries where working and living conditions, as well as opportunities for progress are far better than is the case in Croatia. 
goal was to develop an economy and society based on the idea of competence and social justice. On the other side, the Croats are embarking on a reform based only on the results of the PISA test that they found their education in crisis! Secondly, education does not meet the needs of the labour market: who says this is the main role of education other than neoliberals, of course?

And so, after being diagnosed (Ahec Šonje, 2018), the Croatian educational system is undergoing the CCR. What does the CCR bring to us (17 $^{17}$ The CCR has isolated itself from broader societal problems, the solution of which is a necessary prerequisite for the eventual success of any educational reform. The pandemic problems of corruption, nepotism, dysfunctional judiciary system, political populism, politically controlled media, and the interference of the Church with the spheres that do not belong to it in the secular society, have been put aside. What change can educational reform conceptualiased in this way produce?

Only cosmetic and technical changes can be produced. The old method is replaced by the new one, old question formulation with a new question formulation. ${ }^{18}$ Do we have financial resources for the reform? According to the information transmitted by Hina (2018), the answer is positive: 'the European Commission has supported curricular reform and provided an additional around four million kunas for the technical support in its implementation' (19.1). But the question is: what will the secured funds be used for? The Civic Education Initiative (GOO) argues that the effective resources available to implement the reform are not sufficient 'because as much as 75 percent of the funds are earmarked for the procurement of IT equipment' (Srzić, 2018). What about the remaining funds? Will new textbooks and all supporting materials be published? Maybe. Who will participate in their development? And again we are in the field of the previously described Apple's division of 'conservative modernization' actors.

The textbook development process is an area that requires a continuous dialogue, a predefined but flexible vision, transparency and thinking framed by longterm policies. ${ }^{19}$ In the process of the CCR, the aforementioned dialogue between the Ministry of Science and Education and the publishers has not been established. Instead their communication is about the ultimatums and unilaterally defined

17 Again, a subjective picture that moves away from the declarative and publicly presented goals will be presented here in an attempt to analyse CCR's "hidden curriculum". This is not to say that the actors involved in the reform process are in any way malicious and want to harm children and the state. This means that educational policy takes the ideas offered to it by the professionals and shapes them in a way (which, in their opinion) meets their own needs, provides them with political-ideological dominance and enables them to create some sort of political consensus that keeps them in power. 
guidelines for the development of textbooks. The development of textbooks is required without the curricula of all the educational fields being completed and peer-reviewed, and a clear and unambiguous legal framework defining the process of textbook development has been put in place (Lilek, $8^{\text {th }}$ May 2018; Krštul, $13^{\text {th }}$ May 2018). The textbooks (implicitly in their purpose) contain a question whose knowledge and values is the official knowledge contained in the textbooks? ${ }^{20}$ (Apple, 1982; 2006; 2012)

In the focus of the discussion on teaching materials 'a paradigm shift and an emphasis on problem solving and critical thinking' (Hina, $25^{\text {th }}$ May 2018.) were placed. Minister Divljak emphasizes that 'a big portion of the material will be digitized and a certain part will be made in printed form, but this will not necessarily be a classic book but something much more concise and perhaps simpler. It is not just the fact that the school bag will be 30 percent easier, but also that we have thrown out at least 30 percent of the rote learning' (Hina, $25^{\text {th }}$ May 2018). This is where part of the discourse of the knowledge society (UNESCO, 2006) emerges, in which educational content is digitized and pupils' bags become easier. But the elements of emancipatory education focused on the broader socio-political context and analysis of the sociopolitical power relations do not emerge. There is the domesticated idea of a society based on knowledge society which stops at the change of methods and means. The question is: why there is so much haste for making new textbooks instead of focusing on their quality? The answer is provided by Liessmann's (2008) phantasm of a permanent reform, which does not allow slowing down for reflection.

As it became clear when trying to introduce the Health Education, the attempts of resistance are numerous, and because of the different worldviews of parents, teachers and policy makers, we are ready to forget those who (at least at the declarative level) are the most important in the whole story - students (Krštul, 2017). The same situation is with the Civic Education, which was formally introduced as a cross-curricular theme (Gelenčir, 2016), but the question is how much of its goals is realised in practice (Spajić-Vrkaš, 2015)? What can be deduced from all the above? 'The Conservative modernization' (Apple, 2005; 2006) is healthy and strong in Croatia and anyone who does not like that fact can leave - says no more or less than the president of the country!' (Klauški, 2017)

20 The same question has arisen in the case of the introduction of Health Education in schools. 


\section{TOWARD CONCLUSION}

In this paper which rests on the typology of the actors in the educational policy constructed by Michael W. Apple's, we tried to show the different conceptual and implementational pressures of each individual group of actors in the process of designing and implementing the CCR. In doing so, we used a method of sociopolitical discourse analysis constructed within the public space by dominant actors of neoliberal, neoconservatives, and a class of expert's stakeholders. The sources for the extraction of discourse were the statements on the CCR, which were placed in the public space by the dominant actors of each of the above mentioned groups. The text brings testimonials of some of the leaders of the conservative ( $\mathrm{Net}$. $\mathrm{Hr}$ and Dnevno.hr), liberal (Index.hr) and moderate (Srednja.hr) orientations. The actors analysed are classified as follows: Associations U ime obitelji, Vigilare and Hrast are designated as neoconservative, supranational instances of the World Bank and the European Union and their policies translated into practice through transformations in the labour market in Croatia as the neoliberal actors, and the representatives of HAZU and the Ministry of Science and Education as experts with following value orientations: HAZU as neutral and Ministry of Science and Education as a mixture of neoliberal and conservative orientations resulting from its political orientation.

Following the analysis, we came to the following conclusions. In the context of Croatia, it is justified to approach the analysis of the authoritarian-populist and religious-conservative actors in the educational system as a group united under the neoconservative current. In discussing the CCR, the neoliberals were the most vocal group in the implementational and conceptual terms, pointing to the only possible goal of the educational system, i.e. the ever-increasing degree of employability and international competitiveness of the Croatian economy, and their strength was shown in conception and realization of the 'Schools for life'. The representatives of the neoconservative current were the most vocal in conceptual terms, and by looking at the curricula that form the backbone of the 'School for Life', it becomes apparent that the representatives of this group had a strong value and conceptual influence on the development of teaching materials. Finally, after the initial phase, the representatives of the class of experts almost completely lost their place in the discourse on the CCR and were reduced (by their own will) to the role of observers, who became involved when it was necessary to legitimize the dominant educational discourse. 


\section{REFERENCES}

1. Ahec Šonje, A. (2018). Hrvatsko školstvo je bolesno, ovo je dijagnoza. Express, March $3^{\text {rd }}$. Retrived from https://www.express.hr/top-news/hrvatsko-skolstvo-je-bolesno-ovo-jedijagnoza-14547 (18/3/2018)

2. Apple. W. M. (1982). Education and power $2^{\text {nd }}$ edition. New York and Abingdon: Routledge.

3. Apple, W. M. (2006). Educating the "Right" Way: Markets, Standards, God, and Inequality. Routledge. New York and London.

4. Apple, W. M. (2009). Can critical education interrupt the right? Discourse: Studies in the Cultural Politics of Education. 30 (3): 239-251, Retrived from http://dx.doi. org/10.1080/01596300903036814 (21/10/2018)

5. Apple, W. M. (2012). Ideologija i kurikulum. Beograd: Fabrika knjiga.

6. Baer, J. (2012). Domain Specificity and the Limits of Creativity Theory. Journal of Creative Behaviour, vol. 46 (1). Retrived from https://doi.org/10.1002/jocb.002 (22/7/ 2019)

7. Ball, S. J. (2007). Education plc: Understanding private sector participation in public sector education. London and New York: Routledge.

8. Beroš, I. (2018a). Odgoj i obrazovanje kao područje interdisciplinarne refrakcije i postmoderne reakcije. Noema, III(5): 55-71.

9. Beroš, I. (2018b). Neoliberalizam i obrazovanje: teorijska razmatranja i analiza reakcija obrazovne politike na dominantne društveno-političke trendove u Hrvatskoj promatrane kroz reformski diskurs. Foo2rama, II(2): 31-56.

10. Božić, I. (2018). Ovo je najbolja škola u Hrvatskoj prema uspješnosti učenika na državnoj maturi. Srednja.hr, July $31^{\text {st }}$. Retrived from https://www.srednja.hr/matura/najbolja-skola-hrvatskojprema-uspjesnosti-ucenika-drzavnoj-maturi/ (11/10/2019)

11. Brkulj, V. (2017). June 1. Tko su zapravo tvrdi konzervativci u Nacionalnom vijeću za odgoj i obrazovanje. Tportal.hr. Retrived from https://www.tportal.hr/vijesti/clanak/tko-su-zapravo-tvrdikonzervativci-u-nacionalnom-vijecu-za-odgoj-i-obrazovanje-20170529 (26/10/2018)

12. Ćatić, I. (2012). Kompetencije i kompetencijski pristup obrazovanju. Pedagogijska istraživanja, 9 (1/2), 175-187. Retrived from https://hrcak.srce.hr/113448 (20/7/2019)

13. Fukuyama, F. (1994). Kraj povijesti i posljednji čovjek. Zagreb: Hrvatska sveučilišna naklada.

14. Gee, J. P. (2004). An introduction to discourse analysis: Theory and method. New York, NY: Routledge.

15. Gelenčir, M. (2016). Pogledajte što će se učiti na predmetu Građanski odgoj i obrazovanje. Srednja.hr Februrary 29. Retrived from https://www.srednja.hr/zbornica/pogledaite-sto-ce-seuciti-na-predmetu-gradanski-odgoj-i-obrazovanje-2/ (11/10/2019)

16. Gelenčir, M. (2018). Za sve je kriv tajfun u Kini: Od 74 'Škole za život' tableti stigli u njih 11, a svega četiri se i koriste. Srednja.hr September 21. Retrived from https://www.srednja.hr/novosti/ kriv-tajfun-kini-74-skole-zivot-tableti-stigli-njih-11-a-svega-cetiri-se-koriste/ (11/10/2019)

17. Giroux, A. H. (2011). On critical pedagogy. New York: Continuum.

18. Giroux, A. H. (2014). Neoliberalism's war on higher education. Chicago: Haymarket Books. 
19. Giroux, A. H. (2018a). The public in peril: Trump and the menace of american authoritarianism. New York and London: Routledge.

20. Giroux, A. H. (2018b). American nightmare: Facing the challenge of fascism. San Francisco: City Lights.

21. Gordon, L., Whitty, G. (1997). Giving the'hidden hand'a helping hand? The rhetoric and reality of neoliberal education reform in England and New Zealand. Comparative Education, 33 (3): 453-467.

22. Heck, H. R. (2008). Studying educational and social policy. Mahwah i London: Lawrence Erlbaum Associates.

23. Hina. (2018). Divljak: U jesen eksperimentalna kurikularna reforma, školske torbe za trećinu lakše. Tportal.hr March 25. Retrived from https://www.tportal.hr/vijesti/clanak/divjak-u-jeseneksperimentalna-kurikularna-reforma-skole-torbe-za-trecinu-lakse-foto-20180325 (27/3/2018)

24. Hina. (2018). Novi zamah: Europska komisija dala podršku kurikularnoj reformi i dodatna financijska sredstava. Jutarnji Vijesti - Hrvatska, January 19. Retrived from http://www.matica.hr/ vijenac/545/sto-je-to-neoliberalizam-24097/ (18/3/2018)

25. Howe, M. J. A. (2002). Psihologija učenja. Jastrebarsko: Naklada Slap.

26. Hrvatić, N., Piršl, E. (2007). Kurikulum pedagoške izobrazbe učitelja. In Previšić, V. (Eds.), Kurikulum, teorije, metodologija, sadržaj, struktura. Zagreb: Školska knjiga.

27. Ilišin, V., Bouillet, D., Gvozdanović, A., Potočnik, D. (2013). Mladi u vremenu krize: Prvo istraživanje IDIZ-a i Zaklade Friedrich Ebert o mladima. Zagreb: Institut za društvena istraživanja u Zagrebu and Friedrich Ebert Stiftung.

28. Jarvis, P. (1993). Adult education and the state: Towards a politics of adult education. London and New York: Routledge.

29. Jokić o kurikularnoj reformi: "Činjenica da je krenula i došla do ove razine je zapravo poduzetnička ideja." (2016, April 18.). Dnevnik.hr. Retrived from https://dnevnik.hr/vijesti/ hrvatska/jokic-o-krukularnoj-reformi-cinjenica-da-je-krenula-i-dosla-do-ove-razine-je-zapravopoduzetnicka-ideja---433945.html (24/10/2018)

30. Jurić, V. (2005). Curriculum of contemporary school. Pedagogijska istraživanja, 2 (2), 185-186. Retrived from https://hrcak.srce.hr/139326 (21/7/2019)

31. Jørgensen, M. W., Phillips, L. J. (2002). Discourse analysis as theory and method. London, Thousand Oaks, CA, New Delhi: Sage.

32. Karsten, S. (1999). Neoliberal education reform in the Netherlands. Comparative education, 35(3): 303-317.

33. Klauški, T. (2017). Kolinda prelomila: Tko smatra da ovdje nije dobro, može otići. 24 sata., January 1. Retrived from https://www.24sata.hr/kolumne/kolinda-prelomila-tko-smatra-da-ovdje-nijedobro-moze-otici-507625 (18/3/2018)

34. Keane, M. (2016). Unbundling Precarious Creativity in China: "Knowing-How" and "KnowingTo”. In Curtin M. \& Sanson K. (Eds.), Precarious Creativity: Global Media, Local Labor (pp. 215-230). Oakland, California: University of California Press. Retrived from http://www.jstor.org/ stable/ 10.1525/j.ctt1ffin40.20 (23/7/2019)

35. Kovač, V. (2007). Pristupi analizi obrazovne politike. In Previšić, Vlatko, Šoljan, N. Nikola and Hrvatić, Neven. (Eds.): Pedagogija - prema cjeloživotnom obrazovanju i društvu znanja. Svezak 1: 515-521. Zagreb: Hrvatsko pedagogijsko društvo. 
36. Krštul, D. (2017). May 28. Vlada u Nacionalno vijeće za obrazovanje imenovala ljude bliske HRAST-u i U ime obitelji i profesoricu koja brani 'Za dom spremni'. Srednja.hr. Retrived from https://srednja.hr/novosti/hrvatska/vlada-u-nacionalno-vijece-za-obrazovanje-imenovala-ljudebliske-hrast-u-i-u-ime-obitelii-i-profesoricu-koja-brani-za-dom-spremni/ (21/10/2018)

37. Krštul, D. (2017). November 24. Nemaju zdravstveni odgoj, a više od pola srednjoškolaca u ovom je gradu seksualno aktivno. Srednja.hr. Retrived from https://www.srednja.hr/novosti/ hrvatska/nemaju-zdravstveni-odgoj-a-vise-pola-srednjoskolaca-ovom-gradu-seksualno-aktivno/ $(18 / 3 / 2018)$

38. Krštul, D. (2018). March 13. [Propast cjelovite kurikularne reforme] U 'Školu za život' stižu novi udžbenici, pišu se po nedovršenim kurikulumima. Srednja.hr. Retrived from https://www.srednja. hr/novosti/hrvatska/propast-cjelovite-kurikularne-reforme-skolu-zivot-stizu-novi-udzbenicipisu-se-po-nedovrsenim-kurikulumima/ (17/5/2018)

39. Krštul, D. (2019a). Danas je počela ta Škola za život koju najavljuju godinama, a mi smo izvukli 5 najvećih problema. Telegram. Retrived from https://www.telegram.hr/politika-kriminal/danas-je-pocelata-skola-za-zivot-koju-najavljuju-godinama-a-mi-smo-izvukli-5-najvecih-problema/ (11/10/2019)

40. Krštul, D. (2019b). Ekskluzivno objavljujemo milijunske isplate profesorima u Školi za život. Srednja.hr. Retrived from https://www.srednja.hr/novosti/ekskluzivno-objavljujemo-milijunskeisplate-profesorima-skoli-zivot/ (11/10/2019)

41. Kukec, T. (2017). May 22. Zamijenila Jokića / Na čelu kurikularne reforme je savjetnica ministra Barišića i suradnica Željke Markić. 100 Jutarnji.hr. Retrived from https://100posto.jutarnji.hr/ news/jasminka-buljan-culej-nova-voditeljica-kurikularne-reforme (11/10/2019)

42. Liessmann, P. K. (2008). Teorija neobrazovanosti: Zablude društva znanja. Zagreb: Naklada Jesenski i Turk.

43. Lilek, M. (2016). December 10. Velika analiza uzroka: gdje sve griješimo? Zašto smo loši na PISA testovima i zašto se zbog toga nitko ne uzrujava. Jutarnji Vijesti - Obrazovanje. Retrived from https://www.jutarnji.hr/vijesti/obrazovanje/velika-analiza-uzroka-gdje-sve-grijesimo-zasto-smolosi-na-pisa-testovima-i-zasto-se-zbog-toga-nitko-ne-uzrujava/5373159/ (18/3/2018)

44. Lilek, M. (2018). March 8. Sporni rokovi za izradu udžbenika: Nakladnici na mukama nakon najnovijeg zahtjeva ministrice Divljak: 'Ovo je presedan'. Jutarnji Vijesti - Obrazovanje. Retrived from https://www.jutarnji.hr/ vijesti/obrazovanje/sporni-rokovi-za-izradu-udzbenikanakladnici-na-mukama-nakon-najnovijeg-zahtjeva-ministrice-divjak-ovo-je-presedan/7105797/ $(27 / 10 / 2018)$

45. Lukić, A., Maslov G. (2018). Subjekt neoliberalnoga samoupravljanja: prilog antropologiji kurikularne reforme. Društvena istraživanja, 27(2): 305-326. https://doi.org/10.5559/di.27.2.06.

46. Marsh, C. J. (1994). Kurikulum: temeljni pojmovi. Educa: Zagreb.

47. McLaren, P. (1995). Critical pedagogy and predatory culture: Oppositional politics in a postmodern era. London and New York: Routledge.

48. Mlinarević, V. (2016). Implicitne poruke u skrivenom kurikulumu suvremene škole. Život i škola, LXII (2): 13-25. Retrived from https://hrcak.srce.hr/ 179014 (22/7/2019)

49. Oxfam Development Education Programme. (2006). Teaching controversial issues. Velika Britanija: Oxfam.

50. Paar, V. Šetić, N. (2017). Prilozi za raspravu o obrazovnoj i kurikulnoj reformi: Kritike i vizije („Crvena knjiga“ - treći dio trilogije). Zagreb: HPKZ. 
51. Palekčić, M. (2007). Od kurikuluma do obrazovnih standarda. U: Previšić, V. (ur.) Kurikulumteorije, metodologija, sadržaj, struktura (pp. 39-115). Zagreb: Zavod za pedagogiju, Školska knjiga.

52. Pastuović, N. (1999). Edukologija: integrativna znanost o sustavu cjeloživotnog obrazovanja i odgoja. Zagreb: Znamen.

53. Pauček Šljivak, M. (2018). Februray 6. Željka Markić nije uspjela: Na popisu lektira ostaju autori koje bi ona zabranila. Indeks.hr. Retrived from https://www.index.hr/vijesti/clanak/markic-nijeuspjela-na-popisu-lektira-ostaju-autori-koje-bi-ona-zabranila/1024112.aspx (21/10/2018)

54. Peović Vuković, K. (2017). May 31. Obrazovanje: neokonzervativizam i neoliberalizam. Povodom prosvjeda koji će se održati 1. lipnja za cjelovitu kurikularnu reformu. Retrived from https:// radnickafronta.hr/citaonica/clanci/441-obrazovanje-neokonzervativizam-i-neoliberalizampovodom-prosvjeda-koji-ce-se-odrzati-1-lipnja-za-cjelovitu-kurikularnu-reformu (24/10/2018)

55. Petričušić, A., Čehulić, M. Čepo, D. (2017). Gaining Political Power by Utilizing Opportunity Structures: An Analysis of the Conservative Religious-Political Movement in Croatia. Politička misao, 54 (4): 61-84. Retrived from https://hrcak.srce.hr/190338 (18/10/2018)

56. Royce, O. M. (2010). The Rise and Propagation of Political Right-Wing Extremism: The Identification and Assessment of Common Sovereign Economic and Socio-Demographic Determinants. Retrived from http://dx.doi.org/10.2139/ssrn.1701742 (18/3/2018)

57. Sahlberg, P. (2015). Finnish lessons 2.0: What can the world learn from educational change in Finland?. 2nd ed., New York and London: Columbia University Teachers College.

58. Sekulić-Majurec, A. (2005). Kurikulum nove škole — istraživački izazov školskim pedagozima. Pedagogijska istraživanja, 2 (2): 267-276. Retrived from https://hrcak.srce.hr/139318 $(21 / 7 / 2019)$

59. Sesardić, N. (2018). January 7. Fatamorgana obrazovne reforme: Ugledni hrvatski filozof propituje dosege ulaganja u unaprjeđenje školskog sustava. Jutarnji.hr - Vijesti - obrazovanje. Retrived from https://www.jutarnji.hr/vijesti/obrazovanje/fatamorgana-obrazovne-reformeugledni-hrvatski-filozof-propitkuje-dosege-ulaganja-u-unapredenje-skolskog-sustava/6906738/ $(24 / 10 / 2018)$

60. Sinclair, M. (2004). Learning to live together: Building skills, values and attitudes for the twentyfirst century. Paris: United Nations Educational.

61. Spajić-Vrkaš, V. (Ed.) (2015). (Ne)moć građanskog odgoja i obrazovanja: Objedinjeni izvještaj o učincima eksperimentalne provedbe kurikuluma građanskog odgoja i obrazovanja u 12 osnovnih i srednjih škola (2012./2013.). Zagreb: Nacionalni centar za vanjsko vrednovanje obrazovanja i Istraživačko-obrazovni centar za ljudska prava i demokratsko građanstvo Filozofskoga fakulteta Sveučilišta u Zagrebu.

62. Srzić, A. (2018). April 11. HDZ i HNS, Plenković i Vrdoljak, Divljak i Fuchs i dalje će prodavati maglu. Tportal.hr. Retrived from https:/www.tportal.hr/vijesti/clanak/hdz-i-hns-plenkovic-ivrdoljak-divjak-i-fuchs-i-dalje-ce-prodavati-maglu-foto-20180411 (27/5/2018)

63. UNESCO. (2006). Prema društvima znanja, Zagreb: Educa.

64. Veronika, S. (2017). September 14. Željka Markić: Istanbulska konvencija ide ruku pod ruku s Jokić-Divjak indoktriniranom reformom hrvatskog odgoja i obrazovanja. Kamenjar.com. Retrived from https://kamenjar.com/zelika-markic-istanbulska-konvencija-ide-ruku-pod-ruku-sjokic-divjak-indoktriniranom-reformom-hrvatskog-odgoja-i-obrazovanja/ (21/10/2018) 
65. Vican i Glunčić (2016). September 3. Znanje, poduzetništvo, identitet, solidarnost, temeljne vrednote hrvatske škole. Jutarnji list. Retrived from sa:https://www.jutarnji.hr/vijesti/hrvatska/ vican-i-gluncic-znanje-poduzetnistvo-identitet-solidarnost-temeljne-vrednote-hrvatskeskole/4664591/ (24/10/2018)

66. Vrančić, M., Goldstein, S., Heder, E., Lukić, I., Manojlović, N., i suradnici. 2016. Prijedlog kurikuluma međupredmetne teme Poduzetništvo. Retrived from http://www.kurikulum.hr/ wpcontent/uploads/2016/03/Poduzetnis\%CC\%8Ctvo.pdf (24/10/2018)

67. XXX. (http://vigilare.org/tko-smo/) Retrived (24/10/2018)

68. XXX. (https://uimeobitelji.net/preuzmi/) Retrived (21/10/2018)

69. XXX. "Zemlja znanja (blokada Filozofskog fakulteta u Zagrebu 2009.) CIJELI FILM“. Retrived from https://www.youtube.com/ watch?v=2VT LUmieLM $(21 / 10 / 2018)$

70. XXX. Statut Udruge "U ime obitelji“. Retrived from https://uimeobitelii.net/wp-content/ uploads/2018/09/Statut-17Jul18.-iz-Registra-udruga.pdf (21/10/2018)

71. XXX. (https://www.carnet.hr/usluga/loomen/) Retrived (23/10/2019)

72. Zhao, Y. (2009). Catching up or leading the way: American education in the age of globalisation. Alexiandria: ASCD.

73. Žiljak, T. (2009). Rad na obrazovnoj politici umjesto depolitizacije obrazovanja. Odgojne znanosti, 11(2): 431-446. 


\section{UTJECAJ 'KONZERVATIVNE MODERNIZACIJE' NA ODGOJNO-OBRAZOVNI SUSTAV U HRVATSKOJ: IDEJNI I IMPLEMENTACIJSKI PRITISCI U PROCESU CJELOVITE KURIKULARNE REFORME}

\section{SAŽETAK}

U radu se ukazuje na različite modalitete djelovanja koji su za cilj imali (i još uvijek imaju) transformaciju socijalnih, političkih i ekonomskih društvenih diskursa u smjeru 'konzervativne modernizacije' u većini zapadnih zemalja. Započinje se kratkom povijesnom skicom društveno-političkih okolnosti koje su pružile plodno tlo za nastanak i razvoj 'konzervativne modernizacije', a potom se prelazi na detaljniju razradu koncepta kroz analizu kategorija koje ga sačinjavaju oslanjajući se na radove Michael W. Applea. Appleov teorijski aparat se primjenjuje kao 'alat' za analizu neoliberalnih, neokonzervativnih te ekspertnih idejnih i implementacijskih pritisaka u procesu Cjelovite kurikularne reforme u Hrvatskoj. U zaključnom dijelu rada prikazuju se rezultati analize idejnih i implementacijskih pritisaka različitih aktera u procesu Cjelovite kurikularne reforme u Hrvatskoj.

Ključne riječi: kritička pedagogija, odgojno-obrazovni diskurs, eksplicitni i implicitni ciljevi odgojno-obrazovne reforme, politika obrazovanja, Škola za život 


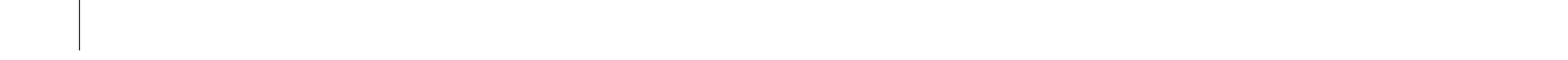

